\title{
8-1962
}

\section{Respiration, electron-transport enzymes, and Krebs-cycle enzymes in early developmental stages of the oyster Crassostrea virginica}

\author{
Robert E. Black \\ Virginia Institute of Marine Science
}

Follow this and additional works at: https://scholarworks.wm.edu/vimsarticles

Part of the Aquaculture and Fisheries Commons, and the Marine Biology Commons

\begin{abstract}
Recommended Citation
Black, Robert E., Respiration, electron-transport enzymes, and Krebs-cycle enzymes in early developmental stages of the oyster Crassostrea virginica (1962). Biological Bulletin, 123(1), 58-70. https://scholarworks.wm.edu/vimsarticles/1773
\end{abstract}




\title{
RESPIRATION, ELECTRON-TRANSPORT ENZYMES, AND KREBS-CYCLE ENZYMES IN EARLY DEVELOPMENTAL STAGES OF THE OYSTER CRASSOSTREA VIRGINICA ${ }^{1}$
}

\author{
ROBERT E. BLACK
}

Department of Biology and Virginia Institute of Marine Science,2 College of William and Mary, Williamsburg, Virginia

A marked increase in the rate of respiration during early development has been noted in many different organisms (see Brachet, 1950; Boell, 1955). In most cases the changes in respiratory enzymes which might contribute to the respiratory increases have not been fully studied. Of particular interest in this connection are studies which have dealt with enzymes of the tricarboxylic acid (citric acid) cycle, as well as those investigations of the enzymes involved in the transfer of electrons between substrates and oxygen, via the systems which oxidize reduced pyridine nucleotides and succinic acid.

Parallels between the increase in respiration and that of cytochrome oxidase have been noted in the grasshopper (Bodine and Boell, 1936; Allen, 1940), the salamander (Boell, 1945), and the chick (Albaum and Worley, 1942; Albaum et al., 1946; Levy and Young, 1948). In Xenopus laevis Boell and Weber (1955) have reported an increase in cytochrome oxidase beginning during cleavage. This is in contrast to the data of Spiegelman and Steinbach (1945) on the developing eggs of Rana pipiens and to those of Petrucci (1957) on cytochrome oxidase during the early development of Bufo bufo. In the developing salamander increases in the activity of succinoxidase have been shown to be similar to those of cytochrome oxidase (Boell, 1948; Krugelis et al., 1952).

Several enzymes of the tricarboxylic acid cycle have been studied in embryos of the chick between the ages of 2 and $6 \frac{1}{2}$ days of incubation by Mahler, Wittenberger and Brand (1958). Aconitase, isocitric dehydrogenase, alpha-keto glutaric dehydrogenase, succinic dehydrogenase, malic dehydrogenase, and fumarase all increased at rates equal to or above that of total embryonic protein up to three days of incubation; following this time only malic dehydrogenase was found to accumulate as rapidly as total protein. On the basis of assays in homogenates these authors concluded that the oxidation of pyruvate by enzymes of the citric acid cycle is probably not the rate-limiting factor in the embryonic respiration. Brand and Mahler (1959) have obtained similar results in the chick in an investigation of enzymes oxidizing reduced diphosphopyridine nucleotide. Diaphorase, DPNHoxidase, and cytochrome oxidase all increased in specific activity until the fourth day of development, after which their rate of accumulation was exceeded by that of other embryonic protein.

In eggs of marine invertebrate animals few studies have been made of changes in

1 This investigation was supported by a grant (G-9847) from the National Science Foundation.

2 Contribution No. 116. 
respiratory enzymes during development. In the sea urchin Gustafson and Hasselberg (1951) found that the activities of succinic dehydrogenase and malic dehydrogenase increased after the mesenchyme-blastula stage. Deutsch and Gustafson (1952) found lower activities of cytochrome oxidase in homogenates of blastulae than in those of cleaving eggs. In an attempt to relate respiratory changes to changes in enzymes, Runnström $(1930,1956)$ has postulated that the terminal oxidase system is present but relatively inactive until the swimming, larval stage is reached in the sea urchin. Black and Tyler (1959) have reached a similar conclusion for eggs of Urechis caupo and Strongylocentrotus purpuratus on the basis of relative rates of oxidation of carbon monoxide in the light and dark by these developing embryos.

In view of the importance of enzymes of the citric acid cycle and the terminal electron-transport system in the respiration of most animals, it is of interest to extend the present knowledge concerning developmental changes in these enzymes to embryos of marine invertebrate animals other than the sea urchin. In the present report, therefore, data on changes in the respiration and in the activities of several respiratory enzymes of early embryos of the oyster, Crassostrea virginica, are presented. Cleland (1951) has demonstrated the presence of most enzymes of the Krebs citric acid cycle in homogenates of oyster eggs, since he obtained respiratory stimulation in such homogenates after the addition of intermediate substrates of this cycle. In addition, succinoxidase and cytochrome oxidase have been shown to be present in the same material by Cleland. The present study is the first in which the existence of a DPNH-oxidase system has been demonstrated and in which direct methods have been used to indicate the presence of enzymes of the Krebs cycle in oyster embryos.

\section{Materials ANd Methods}

Oysters were collected during the spawning season from pilings at Gloucester Point, Virginia, and they were stored in a refrigerated river-water system, in which the salinity was 18 to $20 \mathrm{ppm}$. To obtain gametes, the animals were opened, and portions of the gonads were removed and shaken gently in the water. The eggs were washed by settling and inseminated. The fertilized eggs were washed several times by settling until excess sperm had been removed. The eggs were cultured in a rotating flask at $20^{\circ} \mathrm{C}$. in water of the above salinity containing $0.005 \mathrm{M}$ glycylglycine buffered to $\mathrm{pH} 7.8$. Penicillin (100 units per $\mathrm{ml}$.) and streptomycin (50 micrograms per $\mathrm{ml}$.) were added to all cultures to retard bacterial growth. The concentration of eggs in the rotating flask never exceeded $10^{7}$ per liter.

Since it was difficult to ascertain the percentage of fertilization immediately, eggs were removed for the first measurements of respiration and/or enzyme activity immediately after the first cleavage (about $1-1 \frac{1}{2}$ hours following fertilization). In all experiments reported the percentage of cleaving eggs was better than $85 \%$. Later times at $20^{\circ} \mathrm{C}$. and stages used for subsequent measurements were as follows: 8-10 hours (swimming blastula), 23-25 hours (trochophore), and 48-50 hours (early veliger). Only swimming embryos were used for measurements in blastula, trochophore, and veliger stages.

The eggs or embryos removed for analysis were washed by centrifugation and suspended in a known volume of sea water $(25-50 \mathrm{ml}$.), so that aliquots could be 
taken for counting. From the suspension, five aliquots of 0.5 or $1.0 \mathrm{ml}$. were taken, and these were each diluted to 25 or $50 \mathrm{ml}$. From each diluted aliquot two samples of 0.5 or $1.0 \mathrm{ml}$. were counted, making a total of ten counts (1,000 to 2,000 embryos) in all.

In one series of experiments measurements of respiration were made on living embryos and they were then homogenized in dilute phosphate buffer for measurements of succinic dehydrogenase, DPNH-oxidase, and cytochrome oxidase. For measurements of respiration the embryos were suspended in dilute sea water containing $0.005 M$ glycylglycine, $\mathrm{pH} 7.8$, plus penicillin and streptomycin as indicated above. Aliquots of $2.0 \mathrm{ml}$. were measured into duplicate Warburg vessels of $15-\mathrm{ml}$. capacity and respiration was measured at $25^{\circ} \mathrm{C}$. for one hour. The embryos were then rinsed carefully into centrifuge tubes, packed by centrifugation, resuspended in

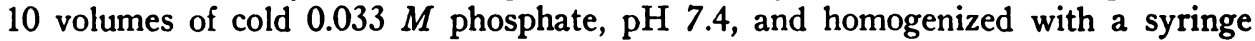
and No. 20 needle. The homogenate was made to a known volume ( 1 to $5 \mathrm{ml}$.) in a calibrated vessel, and aliquots were withdrawn for the determination of the activities of cytochrome oxidase, DPNH-oxidase, and succinic dehydrogenase. Measurements of these activities were completed within $1 \frac{1}{2}$ hours after homogenization.

In other series of experiments measurements of the activities of TPN-specific isocitric dehydrogenase and alpha-ketoglutaric dehydrogenase and of malic dehydrogenase and aconitase were performed. For assaying the first two enzymes, embryos were homogenized in a solution containing $0.3 M$ sucrose and $0.05 M$ Tris (hydroxymethyl) aminomethane, $\mathrm{pH}$ 7.4. The latter two enzymes were assayed in homogenates made in $0.03 M$ Tris, $\mathrm{pH}$ 7.4. All measurements were completed within $1 \frac{1}{2}$ hours after homogenization.

All of the measurements of enzyme activity were performed at $25^{\circ} \mathrm{C}$. With the exception of cytochrome oxidase, which was assayed manometrically, the activities of all enzymes were determined by spectrophotometric methods. For the latter assays, $3.0-\mathrm{ml}$. silica cuvettes of $1-\mathrm{cm}$. light path were used in a Beckman Model DU spectrophotometer. Between readings the cuvettes were incubated in a water bath at $25^{\circ} \mathrm{C}$. or at room temperature of $25^{\circ}$.

All assays were performed at substrate concentrations which allowed initial rates to follow zero-order kinetics. Assays were always performed at two or more levels of homogenate concentration. This provided continuous assurance that reaction rates were directly proportional to the concentration of homogenate in the reaction mixtures. In general, duplicate determinations were made at one concentration of homogenate and a single determination was made at half this concentration. Analyses in which the reaction rate was not proportional to homogenate-concentration or in which the rate of reaction was not constant were discarded. Differences between rates recorded for any pair of duplicates seldom exceeded $10 \%$ of the mean rate for the pair. Details of the assay methods for the enzymes are listed below. (Homogenate percentages given below are approximate, based on volumes of packed embryos.)

Cytochrome oxidase. Manometric method of Schneider and Potter (1943). Warburg vessels contained $0.02 M$ ascorbic acid, $\mathrm{pH} 7.4,2 \times 10^{-4} M$ cytochrome $c$ (based on $\mathrm{M}$. W. of 16,000 ), $0.067 M$ phosphate, $\mathrm{pH} 7.4,6 \times 10^{-4} M$ aluminum chloride, and 0.5 to $1.5 \mathrm{ml}$. of $5 \%$ homogenate. Assays were made at three levels of homogenate concentration, and the auto-oxidation rates of ascorbic acid were 
obtained by extrapolating the rates of oxygen uptake to zero homogenate concentration. After equilibration, readings were taken for 5-10 minutes before tipping in $2 \times 10^{-3} M$ cytochrome $c$ from the side arm. The initial rate of activity was calculated on the basis of three readings taken at 5-minute intervals after the addition of cytochrome $c$ from the side arm. The endogenous oxygen uptake was obtained by subtracting the low rate of auto-oxidation of ascorbic acid in the absence of cytochrome $c$ from the rate of uptake in the vessels before the cytochrome $c$ was added to the main chamber. The endogenous rates of oxygen uptake were usually less than $5 \%$ of the rates in the presence of cytochrome $c$. The auto-oxidation rates of ascorbic acid when both cytochrome $c$ and homogenate were present varied between 60 and 90 microliters per hour in different experiments.

DPNH-oxidase. Spectrophotometric method of Brand and Mahler (1959). The cuvettes contained $1.7 \times 10^{-4} M$ reduced diphosphopyridine nucleotide (DPNH), $3 \times 10^{-6} M$ cytochrome $c, 0.05 M$ phosphate, $\mathrm{pH} 7.4$, and 0.05 to 0.2 $\mathrm{ml}$. of $10 \%$ homogenate. The blank cuvette contained all components except homogenate. After the addition of all substances to blank and experimental cells, they were incubated for 10 minutes at $25^{\circ} \mathrm{C}$. before the first reading was taken. Thereafter readings were taken at 340 millimicrons at 2- to 4-minute intervals for 12 to 20 minutes. No endogenous activity was subtracted from the rates, since controls in several experiments showed that after the initial incubation the $A_{340}$ of homogenate plus cytochrome without added DPNH remained constant. Because of the high absorption of reduced DPN, the use of blank cuvettes without substrate was not feasible.

Succinic dehydrogenase. Spectrophotometric method of Slater and Bonner (1952). The experimental cuvettes contained $0.01 \mathrm{M}$ sodium cyanide, $10^{-8} \mathrm{M}$ potassium ferricyanide, $0.02 M$ sodium succinate, $0.1 \mathrm{M}$ phosphate, $\mathrm{pH} 7.4$, and 0.1 to $0.4 \mathrm{ml}$. of $10 \%$ homogenate. The blank cuvette contained only homogenate in $0.1 \mathrm{M}$ phosphate. After the addition of all components the cuvettes were incubated at $25^{\circ} \mathrm{C}$. for 10 minutes before the first reading was taken. The absorbence at 410 millimicrons was measured at 5- or 10-minute intervals for 25 to 40 minutes.

Isocitric dehydrogenase. Spectrophotometric method of Ochoa (1948). The experimental cuvette contained $0.02 M$ Tris (hydroxymethyl) aminomethane, $\mathrm{pH}$ $7.5,7 \times 10^{-4} M$ isocitrate, $5 \times 10^{-3} M$ sodium cyanide, $4.5 \times 10^{-5} M$ triphosphopyridine nucleotide (TPN), $6 \times 10^{-4} \mathrm{M} \mathrm{MnCl}_{2}$, and 0.1 or $0.2 \mathrm{ml}$ of $10 \%$ homogenate. The blank contained all components except isocitrate. Readings at 340 millimicrons were begun immediately after the addition of homogenate to both blank and experimental cells, and they were continued at 2- or 3-minute intervals for 8-10 minutes.

Alpha-ketoglutaric dehydrogenase. Method of Sanadi and Littlefield (1951). Experimental cuvettes contained $0.1 M$ phosphate, $\mathrm{pH} 7.7,2.5 \times 10^{-8} M$ cocarboxylase, $5 \times 10^{-4} M$ sodium cyanide, $8.6 \times 10^{-5} M$ 2,6-dichlorophenolindophenol, $3.5 \times 10^{-3} M$ magnesium chloride, $6.7 \times 10^{-3} M$ alpha-ketoglutarate, $\mathrm{pH}$ 7.7 , and 0.1 or $0.2 \mathrm{ml}$. of $10 \%$ homogenate. The blank contained all components except substrate. The readings were begun immediately after the addition of homogenate, and 4 readings at 600 millimicrons were taken at 2 -minute intervals. In one experiment ferricyanide was used as the hydrogen acceptor in the assay of this enzyme by the method of Stumpf $e t$ al. (1947). The cuvettes contained similar amounts of all components, except that $10^{-8} M$ potassium ferricyanide was 
substituted for the 2,6-dichlorophenolindophenol, and the decrease in optical density was read at 410 millimicrons for $25-30$ minutes.

Fumarase. Spectrophotometric method of Racker (1950). Experimental cuvettes contained $0.05 M$ malate in $0.05 M$ phosphate, $\mathrm{pH} 7.4$; blank cuvette contained only phosphate. After addition of 0.05 or $0.1 \mathrm{ml}$. of $10 \%$ homogenate to both blank and experimental vessels, the absorbence at 240 millimicrons was measured at 2-minute intervals for 10 minutes.

Malic dehydrogenase. Method of Mehler et al. (1948). The experimental

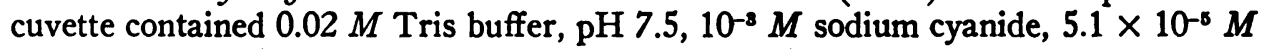
oxalacetate, $\mathrm{pH} 7.5,1.7 \times 10^{-4} \mathrm{M} \mathrm{DPNH}$, and 0.05 to $0.1 \mathrm{ml}$. of $1 \%$ homogenate. The substrate was added last, and readings were taken at 340 millimicrons at 15second intervals for one minute. The oxalacetate solution was prepared just before use and kept on ice. Not more than 10 minutes elapsed between the preparation of this substrate and the enzyme assay. The amounts of pyruvic acid formed by spontaneous decarboxylation of the oxalacetate were considerd to be negligible. At least four determinations of enzyme activity were always made.

Aconitase. Method of Racker (1950). The experimental cuvettes contained

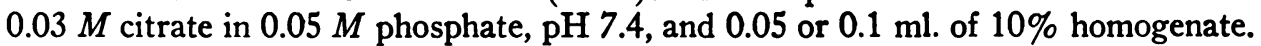
The blank cuvette contained only homogenate and buffer. The increase in absorbence at 240 millimicrons was determined at 2-minute intervals between 5 and 15 minutes after the start of the reaction.

The following values (in $\mathrm{cm}^{2} /$ mole $\times 10^{\circ}$ ) were used for the molar extinction coefficients of the substances used in the assays: DPNH and TPNH, 6.22 at 340 millimicrons (Horecker and Kornberg, 1948), cis-aconitate, 3.30 at 240 millimicrons (Racker, 1950), ferricyanide, 1.00 at 410 millimicrons (Strittmatter and Velick, 1956), and 2,6-dichlorophenolindophenol, 18.5 at 600 millimicrons (Sanadi and Littlefield, 1951).

The sources of materials used in the assays were: Tris (hydroxymethyl) aminomethane, EDTA, citric acid, succinic acid, and ascorbic acid, Will Corporation; potassium ferricyanide and 2,6-dichlorophenolindophenol, Fisher Chemical Company ; DPN (95-100\%), DPNH (Type I, 90-95\%), and thiamine pyrophosphate (cocarboxylase, 80-90\%), Sigma Chemical Company; and cytochrome $c$ ( $0.34 \%$ iron $)$, trisodium isocitrate, alpha-ketoglutaric acid, and oxalacetic acid, Nutritional Biochemicals Corporation.

Stock solutions of coenzymes and substrates used in the assays were made and frozen in several small batches, so that only one or two thawings were necessary in using each batch. Stock solutions of other chemicals were stored at $2-4^{\circ} \mathrm{C}$. Before beginning each experiment, sufficient quantities of all solutions were made so that, with the exception of the assay for malic dehydrogenase, all determinations during any 2-day experiment were made from the same stock solutions. The concentrations of the pyridine nucleotide coenzymes were determined at intervals during some 2-day experiments to ascertain whether decomposition of these materials had occurred during storage.

\section{RESULTS}

Respiration. Cleland (1950) has reported that in the eggs of Ostrea respiration rises at least until the blastula stage. To this author's knowledge, no other investigation of respiratory changes during early development of the oyster has been 
made. The results of the present series of respiration measurements are presented in Table I. The rate of respiration of the blastula was found to be about three times that of the egg at the first cleavage. A further three-fold increase in rate occurred between the blastula stage ( 9 hours) and the trochophore stage ( 24 hours). The respiratory rate of the two-day-old larva (early veliger) was not found to be significantly different from that of the trochophore. The levelling-off of respiratory rate at the trochophore stage is most likely not due to starvation, since oyster embryos cultured at $20^{\circ}$ apparently do not begin feeding until they are about 60 hours old (Amemiya, 1926).

TABLE I

Rates of respiration of developing eggs of Crassostrea virginica. The values represent micromoles of oxygen taken up per minute by one million embryos. Numbers in paren-

theses in headings refer to hours after fertilization. Embryos were grown at $20^{\circ} \mathrm{C}$., and respiration was measured manometrically at $25^{\circ} \mathrm{C}$. for periods of about one hour

\begin{tabular}{|c|c|c|c|c|}
\hline Expt. & $\begin{array}{c}\text { Cleaving eggs } \\
(1-1) \text { hrs.) }\end{array}$ & $\begin{array}{l}\text { Blastulae } \\
\text { (8-10 hrs.) }\end{array}$ & $\begin{array}{l}\text { Trochophores } \\
\text { (23-25 hrs.) }\end{array}$ & $\begin{array}{l}\text { Early veligers } \\
(48-50 \mathrm{hre} .)\end{array}$ \\
\hline $\begin{array}{c}1 \\
2 \\
3 \\
4 \\
5 \\
6 \\
7 \\
8 \\
9 \\
10 \\
\text { Average }\end{array}$ & $\begin{array}{l}0.027 \\
0.024 \\
0.021 \\
0.020\end{array}$ & $\begin{array}{l}0.076 \\
0.045 \\
0.109\end{array}$ & $\begin{array}{r}0.180 \\
0.153 \\
0.219 \\
0.162 \\
0.159 \\
0.215 \\
0.182 \\
0.284 \\
0.203 \\
\\
0.195 \\
\pm 0.039\end{array}$ & $\begin{array}{r}0.139 \\
0.142 \\
0.179 \\
0.234 \\
0.181 \\
0.100 \\
0.163 \\
\pm 0.042\end{array}$ \\
\hline
\end{tabular}

Succinic dehydrogenase, DPNH-oxidase, and cytochrome oxidase. In measuring the activities of these enzyme systems it was desirable to determine the conditions under which maximal rates of electron transfer could occur in homogenates. In preliminary experiments the effects of $\mathrm{pH}$, buffer concentration, and substrate concentration on the activities of the succinic dehydrogenase and DPNH-oxidase were tested. Variation of $\mathrm{pH}$ between 7.2 and 7.8, of succinate between 0.01 and $0.04 M$, of phosphate between 0.05 and $0.15 M$, and of ferricyanide between $10^{-3}$ and $2 \times 10^{-3} M$ had but little effect on the activity of succinic dehydrogenase. In one experiment the rate of reduction of cytochrome $c$ by a homogenate of fertilized eggs was compared with the rate of ferricyanide reduction, when the homogenate was oxidizing succinate. The rate of transfer of electrons to cytochrome $c$ was measured by determining manometrically the activity of the succinoxidase system, in which succinic dehydrogenase is the rate-limiting factor, when cytochrome $c$ is added to the system. This determination, made by the method of Schneider and Potter (1943), indicated that the cytochrome was reduced at a rate about one-third that of the ferricyanide (measured by the spectrophotometric method). This result is similar to that of Green et al. (1955), who found that highly purified preparations of the succinic dehydrogenase complex from beef-heart mitochondria reduced 
TABLE II

Activities of succinic dehydrogenase, DPNH-oxidase, and cytochrome oxidase in homogenates of embryos of the oyster. Homogenates were made in $0.03 \mathrm{M}$ phosphate, $p H 7.4$.

Assays were performed at $25^{\circ} \mathrm{C}$. See text for details of assay systems. Values represent micromoles of substrate (ferricyanide, DPNH, or oxygen) utilized per minute by one million embryos

\begin{tabular}{|c|c|c|c|c|}
\hline Expt. & Cleaving egg & Blastula & Trochophore & Veliger \\
\hline \multicolumn{5}{|c|}{ Succinic dehydrogenase } \\
\hline $\begin{array}{c}1 \\
2 \\
3 \\
4 \\
6 \\
7 \\
8 \\
9 \\
10 \\
\text { Average }\end{array}$ & $\begin{array}{r}0.098 \\
0.145 \\
\pm 0.035\end{array}$ & $\begin{array}{l}0.160 \\
0.090 \\
0.185\end{array}$ & $\begin{array}{r}0.135 \\
0.155 \\
0.175 \\
0.175 \\
0.185 \\
0.105 \\
0.255 \\
0.135 \\
\\
0.164 \\
\pm 0.042\end{array}$ & $\begin{array}{r}0.155 \\
0.130 \\
0.135 \\
0.145 \\
0.085 \\
0.130 \\
\pm 0.024\end{array}$ \\
\hline
\end{tabular}

DPNH-oxidase

\begin{tabular}{|c|c|c|c|c|}
\hline $\begin{array}{c}1 \\
2 \\
3 \\
4 \\
6 \\
7 \\
8 \\
9 \\
10 \\
\text { Average }\end{array}$ & $\begin{array}{r}0.111 \\
0.131 \\
0.118 \\
0.081 \\
\\
\\
\\
0.115 \\
0.111 \\
\pm 0.017\end{array}$ & $\begin{array}{r}0.098 \\
0.088 \\
\\
0.130 \\
\\
\\
\\
0.074 \\
0.098 \\
\pm 0.026\end{array}$ & $\begin{array}{r}0.116 \\
0.077 \\
0.121 \\
0.097 \\
0.129 \\
0.134 \\
0.210 \\
0.167 \\
\\
0.144 \\
\pm 0.035\end{array}$ & $\begin{array}{r}0.083 \\
0.139 \\
0.125 \\
0.085 \\
0.078 \\
0.102 \\
\pm 0.025\end{array}$ \\
\hline \multicolumn{5}{|c|}{ Cytochrome oxidase } \\
\hline $\begin{array}{c}1 \\
2 \\
3 \\
4 \\
6 \\
7 \\
8 \\
9 \\
10 \\
\text { Average }\end{array}$ & $\begin{array}{l}0.383 \\
0.408 \\
0.362 \\
0.362\end{array}$ & $\begin{array}{l}0.445 \\
0.389 \\
\\
0.618\end{array}$ & $\begin{array}{r}0.368 \\
0.578 \\
0.339 \\
0.492 \\
0.337 \\
0.300 \\
{ }^{*}{ }^{*} \\
0.535 \\
0.421 \\
\pm 0.122\end{array}$ & $\begin{array}{r}\overline{0.177}^{*} \\
0.215 \\
0.284 \\
0.330 \\
0.252 \\
\pm 0.059\end{array}$ \\
\hline
\end{tabular}

* Activity not proportional to concentration of homogenate. 
ferricyanide more rapidly than cytochrome $c$ and also more rapidly than several other artificial electron-acceptors.

In preliminary experiments with DPNH-oxidase, it was found that this enzyme system was inhibited about $30 \%$ by a 2 -fold excess of DPNH or by a 2 -fold excess of cytochrome $c$. These effects have also been reported for the DPNH-oxidase system of chick embryos by Brand and Mahler (1959). The optimum $\mathrm{pH}$ for this system was found to be 7.4. The activity of the system was decreased in phosphate concentrations below $0.05 M$, and occasionally was found to be somewhat higher in $0.1 M$ than in $0.05 M$ buffer; however, the latter effect was not consistently obtained. In several experiments the activity of the DPNH oxidase was shown to be inhibited $95 \%$ or more by $10^{-3} M$ cyanide. In the absence of added cytochrome, the DPNH oxidase activity was very low in most experiments.

Since the activity of cytochrome oxidase was always greater than the combined activities of the two systems above, no special effort was made to determine the conditions for maximal activity of this enzyme. In preliminary experiments it was found that neither the concentration of cytochrome $c$ nor that of ascorbic acid was a limiting factor in the assays. The effects of variation of $\mathrm{pH}$ or buffer concentration were not tested.

The results of measurements of these components of the electron transport system are presented in Table II. Since relatively large amounts of homogenate were required for the assays, the experiments were divided into two series. In the first, measurements were made betwen the first cleavage and 24 hours; in the second the rates of enzyme activity in 24- and 48-hour stages were compared. No consistent change was observed in the activity of succinic dehydrogenase or of DPNH oxidase during development to the veliger. (The average value for DPNH oxidase at 24 hours is $30-40 \%$ higher than those in the blastula and veliger; this difference is considered to be too small to be significant in view of the variation between values obtained at each stage in different experiments.)

Cytochrome oxidase is also nearly constant in activity up to the trochophore stage. A considerable decrease in the activity of this enzyme between 24 and 48 hours was found in most experiments; moreover, in one measurement at each of these stages the activity was not proportional to the concentration of homogenate. These findings may indicate the presence of an inhibitor of this enzyme in late stages, as suggested by Deutsch and Gustafson (1952) for homogenates of sea urchin blastulae. A slight clumping of homogenates of trochophores and veligers usually occurred in the presence of $2 \times 10^{-4} M$ cytochrome $c$. This did not appear to affect the relationship between concentration of homogenate and enzyme activity in most manometric experiments. In lesser concentrations, such as those used in the assay of DPNH oxidase, no clumping of the homogenates occurred.

A comparison of respiratory rates during development (Table I) with the enzyme activities reported in Table II shows that the terminal enzyme systems must transfer electrons at an increasing rate as development progresses in order to account for the increase in respiration. Such an increased rate of transfer could be due to the greater rate of production of succinate and reduced pyridine nucleotides, or it could be a result of the synthesis of some rate-limiting component of the terminal system, such as cytochrome $c$. Cytochrome $c$ was not a limiting factor in any of the assay-systems; it is therefore not possible from present data to determine 
whether it is rate-limiting for the respiration at any stage of development. Data presented in the next section indicate that at least two of the enzymes of the citric acid cycle do increase in activity during one phase of development.

Isocitric dehydrogenase and alpha-ketoglutaric dehydrogenase. The levels of activity of these enzymes at each embryonic stage investigated are listed in Table III. In contrast to the terminal enzymes, a marked increase in the activity of isocitric dehydrogenase was observed between 9 and 24 hours in all experiments. Thus in the trochophore the level of this enzyme is about three times the level in the blastula. This increase is about equivalent to the increase in respiration during the same

TABLE III

Activities of isocitric and alpha-ketoglutaric dehydrogenases in homogenates of oyster embryos. Homogenates were made in $0.3 \mathrm{M}$ sucrose and $0.05 \mathrm{M}$ Tris (hydroxymethyl) aminomethane, $p H$ 7.4. Assays were performed at $25^{\circ} \mathrm{C}$. (for details see text). Values represent micromoles of substrate utilized per million embryos per minute

\begin{tabular}{|c|c|c|c|c|}
\hline Expt. & Cleaving egg & Blastula & Trochophore & Veliger \\
\hline \multicolumn{5}{|c|}{ Isocitric dehydrogenase } \\
\hline $\begin{array}{c}11 \\
12 \\
13 \\
14 \\
15 \\
16 \\
\text { Average }\end{array}$ & $\begin{array}{l}0.080 \\
0.069 \\
0.050 \\
0.104 \\
0.083 \\
0.098 \\
0.097 \pm 0.024\end{array}$ & $\begin{array}{l}0.070 \\
0.043 \\
0.131 \\
0.088 \\
0.109 \\
0.088 \geq 0.030\end{array}$ & $\begin{array}{l}0.330 \\
0.210 \\
0.190 \\
0.146 \\
0.284 \\
0.272 \\
0.239 \pm 0.060\end{array}$ & $\begin{array}{l}0.100 \\
0.150 \\
0.140 \\
0.289 \\
0.277 \\
0.256 \\
0.202 \pm 0.074\end{array}$ \\
\hline \multicolumn{5}{|c|}{ Alpha-ketoglutaric dehydrogenase } \\
\hline $\begin{array}{c}11^{*} \\
13 \\
14 \\
15 \\
\text { Average }^{* *}\end{array}$ & $\begin{array}{l}0.084^{*} \\
0.024 \\
0.021 \\
0.028 \\
0.024 \pm 0.003\end{array}$ & $\begin{array}{l}0.018 \\
0.021 \\
0.020 \\
0.020 \pm 0.001\end{array}$ & $\begin{array}{l}0.220^{*} \\
0.055 \\
0.038 \\
0.050 \\
0.048 \pm 0.007\end{array}$ & $\begin{array}{l}0.290^{*} \\
0.033 \\
0.038 \\
0.058 \\
0.043 \pm 0.011\end{array}$ \\
\hline
\end{tabular}

* Assayed with ferricyanide.

** Data for 2,6 dichlorophenolindophenol only.

period. In no case was any increase in this enzyme observed prior to the blastula stage. In some experiments, decreases in the activity of isocitric dehydrogenase were found between 24 and 48 hours. The activity of this enzyme was nearly $100 \%$ higher in sucrose homogenates than in homogenates made in $0.03 M$ Tris. The addition of sucrose to homogenates made in dilute buffer also enhanced the activity by as much as $50 \%$. The reason for this effect is not known.

The levels of activity of alpha-ketoglutaric dehydrogenase, shown in Table IV, indicate that approximately a 2.5 -fold increase in the activity of this enzyme occurs between 9 and 24 hours of development. As in the case of isocitric dehydrogenase, little change in the activity of this enzyme occurs during cleavage or during development from trochophore to veliger. In one experiment the rate of reduction of ferri- 
cyanide was used as a measure of the activity of this enzyme. This hydrogen acceptor was reduced at a rate which was 5-10 times higher than that of the 2,6-dichlorophenolindophenol; however, the high molar extinction of the latter made it more desirable for assays of homogenates with low activities. The assays were complicated by the high rates of endogenous reduction of this dye, and by the rapid loss of enzyme activity with either acceptor. In most homogenates prepared in dilute Tris or phosphate buffer, the activity of alpha-ketoglutaric dehydrogenase was too low to measure. Data are therefore presented only for homogenates made in buffered sucrose.

TABLE IV

Activities of malic dehydrogenase and aconitase in homogenates of oyster embryos. Homogenates were made in $0.03 \mathrm{M}$ Tris buffer, $\mathrm{pH} 7.4$. Assays were performed at $25^{\circ} \mathrm{C}$. Values represent micromoles of substrate utilized per minute by one million embryos

\begin{tabular}{|c|c|c|c|c|}
\hline Expt. & Cleaving egg & Blastula & Trochophore & Veliger \\
\hline \multicolumn{5}{|c|}{ Malic dehydrogenase } \\
\hline $\begin{array}{c}17 \\
18 \\
19 \\
20 \\
21 \\
22 \\
\text { Average }\end{array}$ & $\begin{array}{r}9.2 \\
10.0 \\
8.5 \\
7.0 \\
8.0 \\
8.5 \\
8.5 \pm 0.9\end{array}$ & $\begin{array}{r}9.3 \\
10.5 \\
8.2 \\
9.1 \\
8.1 \\
9.2 \pm 0.8\end{array}$ & $\begin{array}{r}15.6 \\
14.5 \\
10.3 \\
7.7 \\
7.2 \\
7.0 \\
10.4 \pm 3.5\end{array}$ & $\begin{array}{l}10.0 \\
12.0 \\
12.6 \\
8.0 \\
9.3 \\
6.0 \\
9.7 \pm 2.2\end{array}$ \\
\hline \multicolumn{5}{|c|}{ Aconitase } \\
\hline $\begin{array}{c}17 \\
18 \\
19 \\
20 \\
21 \\
\text { Average }\end{array}$ & $\begin{array}{l}0.068 \\
0.082 \\
0.080 \\
0.095 \\
0.100 \\
0.085 \pm 0.011\end{array}$ & $\begin{array}{l}0.082 \\
0.080 \\
0.088 \\
0.110 \\
0.110 \\
0.094 \pm 0.013\end{array}$ & $\begin{array}{l}0.123 \\
0.110 \\
0.120 \\
0.063 \\
0.065 \\
0.096 \pm 0.026\end{array}$ & $\begin{array}{l}0.106 \\
0.090 \\
0.090 \\
0.104 \\
0.070 \\
0.093 \pm 0.013\end{array}$ \\
\hline
\end{tabular}

Fumarase, malic dehydrogenase and aconitase. Efforts to measure fumarase in whole homogenates, prepared in either sucrose or in dilute buffer, were unsuccessful. Although the enzyme was found to be present in all stages by the spectrophotometric method, its activity was extremely low and was not proportional to the homogenate concentration in most cases. In contrast to fumarase, the activity of malic dehydrogenase is extremely high in all stages of development, being at least 20 times that of any other enzyme measured (Table IV). High activities have been noted for this enzyme in other animal tissues (cf. Krebs and Lowenstein, 1960). Little change in activity was found during development to the veliger stage.

The presence of aconitase in all stages of development is of interest, since this enzyme has been reported to be absent from adult oyster-mantle (Jodrey and Wilbur, 1955). As in the case of malic dehydrogenase, no change in activity occurs during any phase of early development (Table IV). Neither the activity of 
aconitase nor that of malic dehydrogenase was affected by the composition of the medium used for homogenization; the data are therefore given for homogenates made in $0.03 M$ Tris buffer.

\section{Discussion}

The data reported above indicate that: (1) although respiration increases 3-fold during cleavage, little change in activity of any of the enzymes of the citric acid cycle occurs before the blastula stage is reached; $(2)$ a further 3 -fold increase in respiration between blastula and trochophore stages is paralleled by increases in two enzymes of the Krebs cycle; and (3) between trochophore and veliger stages there is little change in respiration or in enzyme activity, with the possible exception of a decrease in cytochrome oxidase. With regard to the period of cleavage, the results are similar to those of Gustafson and Hasselberg (1951) for the sea urchin and to those of Spiegelman and Steinbach (1945) and Petrucci (1957) for two amphibians. Following the blastula stage of the oyster marked increases were found in the activities of isocitric dehydrogenase and alpha-ketoglutaric dehydrogenase. Such increases in activity of two enzymes which are "biochemically adjacent" in the citric acid cycle are of considerable interest, and it would be desirable to determine whether the changes occur simultaneously or sequentially.

No change in activity of most enzymes of the Krebs cycle or of the electrontransport system occurs during development to the veliger stage in the oyster. This finding is in contrast to that of Gustafson and Hasselberg (1951) for the sea urchin, in which both succinic dehydrogenase and malic dehydrogenase increase 4- to 5-fold between blastula and pluteus stages. These authors have postulated that an increase in the number of mitochondria is responsible for changes in activity of these and other enzymes during this period of development. Counts of granules exhibiting the staining properties of mitochondria in developing sea urchins have given supporting evidence for this hypothesis, since the number of these granules apparently increases during about the same period of development (Gustafson and Lenicque, 1952; Shaver, 1956).

In the unfertilized egg of the oyster Cleland (1951) has obtained evidence for the localization of succinic oxidase and cytochrome oxidase in cytoplasmic granules, and he has shown that removal of the granules from homogenates by centrifugation drastically reduces the ability of the homogenates to take up oxygen in the presence of substrates of the Krebs cycle. This latter finding may be simply due to the removal of the terminal electron-transport systems, which would reduce the respiration of the homogenates even in the presence of substrate. Since his results clearly indicate the localization of succinic oxidase and cytochrome oxidase in the large granules, it is possible to conclude from the present study that any changes in number of granules during development of the oyster are not accompanied by changes in these terminal enzymes. Data on the concentrations of other enzymes of the citric acid cycle in the large granule fraction from homogenates of eggs and larvae are presented in an accompanying report (Black, 1962).

The author is indebted to Mr. James Egan and to Miss Lynn Search for their technical assistance during this investigation. A preliminary report of these results has been previously published (Black, 1960). 


\section{SUMMARY}

1. Measurements of respiration, cytochrome oxidase, and the DPNH oxidase system, as well as five enzymes of the citric acid cycle, aconitase, isocitric dehydrogenase, alpha-ketoglutaric dehydrogenase, succinic dehydrogenase, and malic dehydrogenase, have been made in oyster embryos between the first cleavage and the early veliger stage. The rate of respiration increases 9-fold to the trochophore stage and levels off until the veliger stage is reached. Succinic dehydrogenase, DPNH oxidase, malic dehydrogenase and aconitase were not found to change appreciably during development to the veliger. Cytochrome oxidase showed no significant change prior to the trochophore stage, but decreases were found in this enzyme after this stage. Isocitric dehydrogenase and alpha-ketoglutaric dehydrogenase were found to increase, paralleling the increase in respiration, between the blastula and trochophore stages. Following this stage, these enzymes remain constant in activity up to the veliger stage.

2. The results are shown to be in contrast to those obtained for the sea urchin by other workers. The possible relationships between changes in enzyme activities and increases in respiratory rate are considered.

\section{LITERATURE CITED}

Albaum, H. G., and L. G. Worley, 1942. The development of cytochrome oxidase in the chick embryo. J. Biol. Chem., $144: 697-700$.

Albaum, H. G., A. B. Novikoff and M. Ogur, 1946. The development of the cytochrome oxidase and succinoxidase systems in the chick embryo. J. Biol. Chem., 165: 125-130.

AlleN, T. H., 1940. Enzymes in ontogenesis. XI. Cytochrome oxidase in relation to respiratory activity and growth of the grasshopper egg. J. Cell. Comp. Physiol., 16: 149-163.

Amemiya, I., 1926. Notes on experiments on the early developmental stages of the Portugese, American, and English native oyster, with special reference to the effect of varying salinity. J. Mar. Biol. Assoc., 14 : 161-175.

BLACK, R. E., 1960. Krebs-cycle dehydrogenases, DPNH-oxidase and cytochrome oxidase in homogenates of developing oyster-eggs. Anat. Rec., 138: 335.

BlACK, R. E., 1962. The concentrations of some enzymes of the citric acid cycle and electron transport system in the large granule fraction of eggs and larvae of Crassostrea virginica. Biol. Bull., 123: 71-79.

Black, R. E., AND A. Tyler, 1959. Effects of fertilization and development on the oxidation of carbon monoxide by eggs of Strongylocentrotus and Urechis as determined by use of C13. Biol. Bull., 117: 443-453.

Bodine, J. H., ANd E. J. Boell, 1936. Enzymes in ontogenesis. II. The indophenol oxidase. J. Cell. Comp. Physiol., 8: 213-230.

BoEll, E. J., 1945. Functional differentiation in embryonic development. II. Respiration and cytochrome oxidase activity in Amblystoma punctatum. J. Exp. Zool., 100: 331-352.

Boell, E. J., 1948. Biochemical differentiation during amphibian development. Ann. N. Y. Acad. Sci., 49: 773-800.

BoEll, E. J., 1955. Energy exchange and enzyme development during embryogenesis. In: Analysis of Development, B. H. Willier, P. A. Weiss, and V. Hamburger, eds., W. B. Saunders, Philadelphia.

BOELl, E. J., AND R. WeBER, 1955. Cytochrome oxidase in mitochondria during amphibian development. Exp. Cell Res., 9: 559-567.

Brachet, J., 1950. Chemical Embryology. Interscience Publishers, New York.

Brand, L., and H. R. Mahler, 1959. Biochemical studies of the developing avian embryo. III. The oxidation of reduced pyridine nucleotide. J. Biol. Chem., 234 : 1615-1624.

Cleland, K. W., 1950. Respiration and cell division in developing oyster eggs. Proc. Linn. Soc. N. S. W., 75: 282-295. 
Cleland, K. W., 1951. The enzymatic architecture of the unfertilized oyster egg. Aust. J. Exp. Biol. Med. Sci., 29 : 35-45.

Deutsch, H. F., and T. Gustafson, 1952. The changes in catalase and cytochrome oxidase activity in developing sea urchin eggs. Arkiv Kemi, 4: 221-231.

Green, D. E., S. Mir AND P. M. KonOUT, 1955. Studies on the terminal electron transport system. I. Succinic dehydrogenase. J. Biol. Chem., 217 : 551-567.

Gustafson, T., AND I. Hasselberg, 1951. Studies on enzymes in the developing sea urchin egg. Exp. Cell Res., 2 : 642-672.

Gustafson, T., AND P. Lenicgue, 1952. Studies on mitochondria in the developing sea urchin egg. Exp. Cell Res., 3: 251-274.

Hogeboom, G. H., AND W. C. SCh NeIder, 1950. Cytochemical studies of mammalian tissues. III. Isocitric dehydrogenase and triphosphopyridine nucleotide-cytochrome $c$ reductase of mouse liver. J. Biol. Chem., $186:$ 417-427.

Horecker, B. L., AND A. KoRnBERG, 1948. The extinction coefficients of the reduced band of pyridine nucleotides. J. Biol. Chem., $175: 385-390$.

Jodrey, L. H., AND K. M. WILBUR, 1955. Studies on shell formation. IV. The respiratory metabolism of the oyster mantle. Biol. Bull., 108: 346-358.

Krebs, H. A., ANd J. M. Lowenstein, 1960. In: Metabolic Pathways, ed. by David M. Greenberg. Academic Press, New York.

KrUgelis, E. J., J. S. Nicholas and M. E. Vosginn, 1952. Alkaline phosphatase activity and nucleic acids during embryonic development of Amblystoma punctatum at different temperatures. J. Exp. Zool., 121: 489-504.

Levy, M., AND N. F. Young, 1948. Chemistry of the chick embryo. V. Accumulation of cytochrome oxidase. J. Biol. Chem., $175:$ 73-77.

Mahler, H. R., M. H. Wittenberger AND L. Brand, 1958. Biochemical studies of the developing avian embryo. II. Enzymes of the citric acid cycle. J. Biol. Chem., 233: 770-782.

Mehler, A. H., A. Kornberg, S. Grisola and S. OchoA, 1948. The enzymatic mechanism of oxidation-reduction between malate or isocitrate and pyruvate. J. Biol. Chem., 174: 961-977.

Oснол, S., 1948. Biosynthesis of tricarboxylic acids by carbon dioxide fixation. III. Enzymatic mechanisms. J. Biol. Chem., 174: 133-157.

PetruccI, D., 1957. Citocromo-ossidasi e respirazione nell' embryo-genesi degli anfibi anuri. Acta Embryologiae et Morphologiae Experimentalis, 1: 105-117.

RACKER, E., 1950. Spectrophotometric measurements of the enzymatic formation of fumaric and cis-aconitic acids. Biochim. et Biophys. Acta, $4: 211-214$.

RunNström, J., 1930. Atmungsmechanismus und Entwicklungserregung bei dem Seeigelei. Protoplasma, 10: 106-173.

Runnström, J., 1956. Some considerations on metabolic changes occurring at fertilization and during early development of the sea urchin egg. Pubbl. Stasione Napoli, 28: 315-340.

SANadi, D. R., AND J. W. Littlefield, 1951. Studies on $\alpha$-ketoglutaric oxidase. I. Formation of "active" succinate. J. Biol. Chem., 193: 683-689.

SCh Neider, W. C., AND V. R. PotTer, 1943. The assay of animal tissues for respiratory enzymes. II. Succinic dehydrogenase and cytochrome oxidase. J. Biol. Chem., 149: 217-227.

Shaver, J. R., 1956. Mitochondrial populations during development of the sea urchin. Exp. Cell Res., 11 : 549-559.

Slater, E. C., AND W. D. Bonner, 1952. The effect of fluoride on the succinic oxidase system. Biochem. J., 52: 185-195.

Spirgelman, S., AND H. B. Steinbach, 1945. Substrate-enzyme orientation during embryonic development. Biol. Bull., 88 : 254-257.

StrittMatter, P., ANd S. F. Velick, 1956. A microsomal cytochrome reductase specific for diphosphopyridine nucleotide. J. Biol. Chem., 221 : 277-286.

Stumpr, P. K., Z. ZarudnayA ANd D. E. Green, 1947. Pyruvic and $\alpha$-ketoglutaric oxidase of animal tissue. J. Biol. Chem., $167:$ 817-825. 